\title{
Inventarisasi Jenis-Jenis Nyamuk Di Desa Alindau, Donggala, Sulawesi Tengah
}

\section{Inventory Of Mosquitoes From Alindau, Donggala, Central Sulawesi}

\author{
Moh. Sabir*), Annawaty dan Fahri \\ Jurusan Biologi, Fakultas MIPA Universitas Tadulako, \\ J1.Soekarno Hatta km 9 Tondo, Palu 94118 Sulawesi Tengah
}

\begin{abstract}
The objective of this study was to identify the mosquitosfrom Alindau, Donggala, Central Sulawesi. Samples collecting were done in March 2015 and April 2015 based on landing collection technique. Sampling location was divided to 4 habitat i.e paddy field, farm, shore and settlement. In this study, we collected 232 individu of mosquitoes that belonging to four genera and eleven species. Two species namely:Ae. albopictus and Ae.vexans were belonging to genus of Aedes, Two species;Ar. kuchingensis and Ar. subalbatus were belonging to genus of Armigeres, two species:An. peditaeniatus, and An. vagus belonging to genus Anopheles. The most common species are Culex which is consist of 4 species such as $C x$. gellidus, $C x$. hutchinsoni, $C x$. qunquefasciatus and $C x$. vishnui
\end{abstract}

Key words: Aedes, Anopheles, Armigeres, Culex, Alindau, Central Sulawesi

\begin{abstract}
ABSTRAK
Penelitian ini untuk mengetahui jenis-jenis nyamuk yang terdapat di Desa Alindau Kecamatan Sindue Tobata Kabupaten Donggala Provinsi Sulawesi Tengah. Koleksi sampel dilakukan pada bulan Februari sampai Maret 2015menggunakan metode landing collection technique. Lokasi sampling dibagi menjadi 4 habitat yang berbeda yaitu sawah, kebun, pantai dan pemukiman yang berada di Desa Alindau.Berdasarkan koleksi spesimen nyamuk sebanyak 232 individu, diperoleh 11 jenis yang tergolong kedalam 4 genus yaitu Aedes, Anopheles, Armigeres, dan Culex. Genus Aedesyang ditemukan terdiri dari 2 spesies yaitu Ae.albopictusdanAe.vexans sedangkangenus Anopheles sebanyak 3 spesies yaitu Anopheles indefinitus, An. peditaeniatus, dan An. vagus. Genus Armigeres ditemukan sebanyak 2 spesies yaitu Ar. kuchingensis dan Ar. subalbatus dan genus yang anggotanya paling banyak ditemukan adalah genus Culex sebanyak 4 jenis yaitu $C x$. gellidus, Cx. hutchinsoni, $C x$. qunquefasciatus dan $C x$. vishnui.
\end{abstract}

Kata Kunci: Aedes, Anopheles, Armigeres, Culex, Alindau, Sulawesi Tengah 


\section{LATAR BELAKANG}

Serangga mempunyai peranan positif terhadap manusia namun ada pula serangga yang merugikan manusia, seperti serangga yang menjadi vektor yang menularkan wabah penyakit.Sejak abad ke-17 sampai awal abad ke-20, tercatat bahwa penyakit yang ditularkan oleh nyamuk atau serangga vektor lebih benyak terjadi dibandingkan penyakit lainnya (Gubler, 1998). Besarnya kerugian yang ditimbulkan oleh penyakit menular serangga vektor menyebabkan perlunya pengendalian populasi serangga vektor sampai batas yang dapat ditolerir manusia.

Nyamuk (Ordo Diptera, Kelas Insecta) merupakan salah satu ektoparasit, karena memiliki tingkat interaksi yang tinggi dengan manusia dan berperan sebagai vektor dari berbagai penyakit (Departemen Kesehatan, 2003). Identifikasi morfologi yang tepat dapat berguna untuk mengetahui karakter dan jumlah spesies sehingga memberikan gambaran keanekaragaman di suatu daerah. Serta upaya dalam penanganan dan pengendalian penyebaran nyamuk di suatu daerah/geografi (Fahmi, 2014).

Menurut Dharmawan (1993) nyamuk memiliki waktu aktif menggigit yang berbeda, yaitu kelompokan diurnal, nokturnal dan crepusculatar. Nyamuk diurnal merupakan nyamuk yang aktif selama pagi hingga sore hari, nyamuk nokturnal merupakan nyamuk aktif ketika malam hari, sedangkan nyamuk crepuscular merupakan nyamuk yang aktif sepanjang hari.

Pengendalian vektor merupakan unsur utama dalam keberhasilan program pemberantasan penyakit menular yang disebabkan oleh serangga vektor di Indonesia. Sebagai dasar untuk menentukan strategi pengendalian vektor secara tepat guna adalah identifikasi spesies secara akurat dan memahami bio-ekologinya secara rinci (Lestari, 2007).

Desa Alindau yang terletak di Kecamatan Sindue Tobata, Kabupaten Donggala, Sulawesi Tengah yang merupakan daerah dataran rendah yang memiliki beberapa jenis habitat seperti persawahan, rawa-rawa, sungai dan lahan perkebunan. Kondisi lingkungan yang demikian merupakan habitat yang kondusif dan sesuai untuk perkembangbiakan nyamuk. Tulisan ini membahas mengenai jenis-jenis nyamuk serta keanekaragaman nyamuk yang terdapat di Desa Alindau.

\section{BAHAN DAN METODE}

\section{Waktu dan Tempat Penelitian}

Penelitian telah dilakukan pada bulan Februari sampai Maret 2015, di Desa Alindau Kecamatan Sindue Tobata Kabupaten Donggala. Lokasi pengambilan sampel dilakukan pada empat habitat yaitu 
pemukiman masyarakat, pantai, kebun dan sawah (Gambar 1). Identifikasi morfologi nyamuk dilakukan di Laboratorium Biodiversitas Fakultas Matematika dan Ilmu Pegetahuan Alam Universitas Tadulako, Palu, Sulawesi Tengah.

\section{Metode Penelitian}

Penelitian menggunakan metode koleksi individu setiap spesies, dan nilai bebas dengan menggunakan 4 habitat atau lokasi sampling yang berbeda yaitu sawah, berdasarkan persamaan: kebun, pantai dan pemukiman yang berada $\quad \mathrm{H}^{\prime}=-\Sigma($ pi ln pi)

di sekitaran Desa Alindau Kecamatan Sindue

Tobata Kabupan Donggala Provinsi Sulawesi Tengah. Sampel yang telah dikoleksi kemudian diidentifikasi menggunakan buku kunci bergambar nyamuk Indonesia. Oleh C.T. O’Connor dan Soepanto, tahun 1999. Sampel yang telah diidentifikasi, kemudian di hitung jumlah keanekaragaman Shannon-Wiener

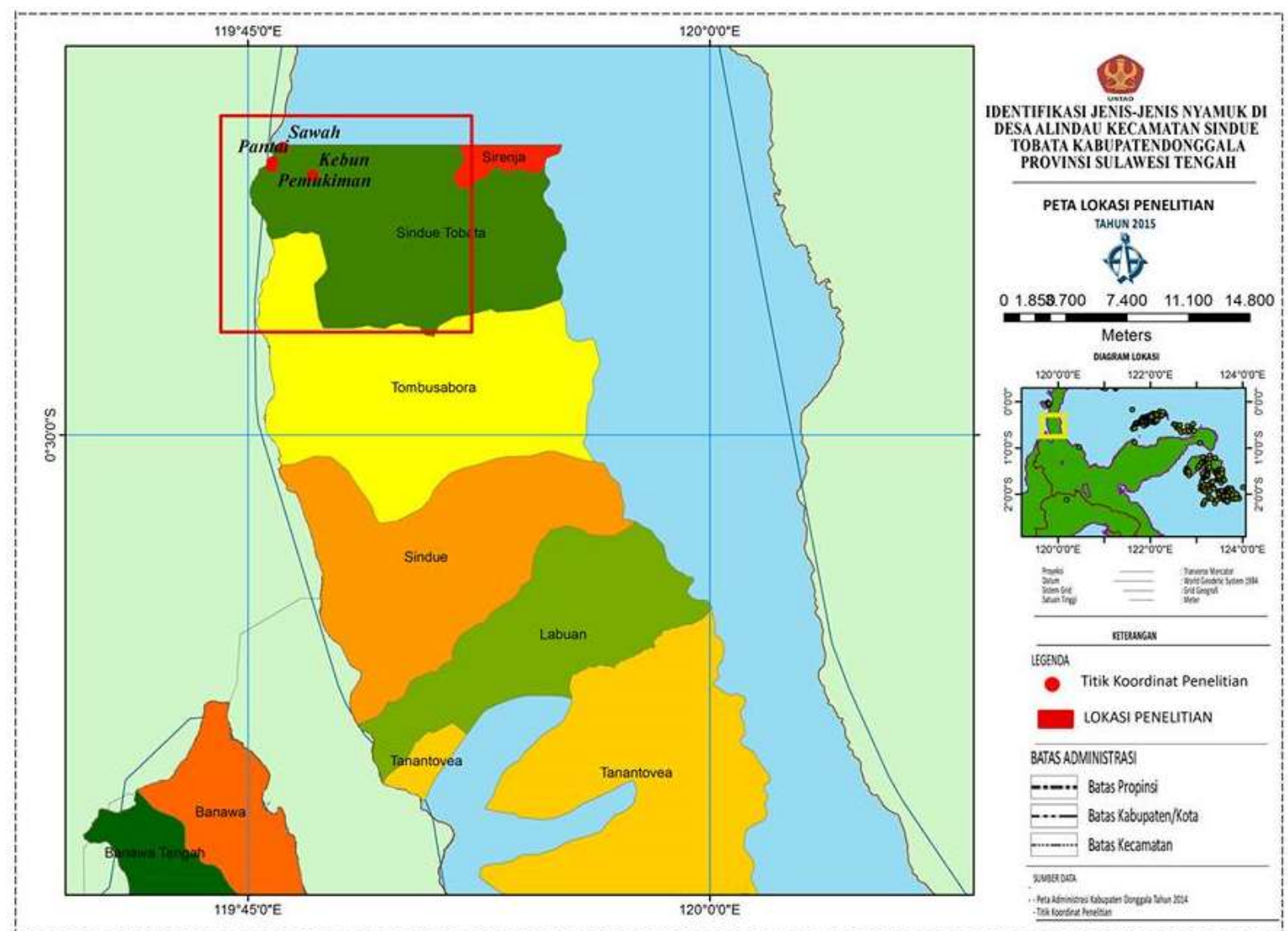

Gambar 1 Peta lokasi penelitian di Desa Alindau

\section{HASIL DAN PEMBAHASAN}

Sebanyak 232 individu yang tergolong dalam 4 genus dan 11 spesies nyamuk di Desa Alindau, Kecamatan Sindue Tobata,
Kabupaten Donggala, Provinsi Sulawesi Tengah.Genus Aedes sebanyak 2 spesies yaitu Ae. albopictus dan dan Ae. vexans. Genus Anopheles sebanyak 3 spesies yaitu 
Anopheles indefinitus, An. peditaeniatus, An. vagus. Genus Armigeres sebanyak 2 spesies yaitu Ar. kuchingensis dan Ar. subalbatus. Genus Culex sebanyak 4 spesies yaitu $C x$. gellidus, $\quad C x$. hutchinsoni, $C x$. qunquefasciatus, dan Cx. visnui (Tabel 1). Di habitat pemukiman ditemukan nyamuk dengan jumlah 7 spesies dan didominasi oleh spesies $C x$. vishnui dengan jumlah 54 individu.CX. vishnui juga merupakan spesies yang mendominasi habitat sawah dengan jumlah 26 individu. Toma et al.,(2015) melaporkan bahwa $C x$. vishnui ditemukan pada habitat sawah barsama dengan Culex lainnya seperti $C x$. tritaeniorhyncus dan $C x$. pseudovishnui di Ishingakijima dan Iriomotejima (Jepang). Boesri dkk. (2002) mengkoleksi nyamuk $C x$. vishnui ditemukandi habitat sawah dan Desa. Boesri (2011) melaporkan bahwa Cx. vishnui ditemukan beristirahat di tanaman padipadian dan tidak ditemukan divegetasi lainnya di India. Di habitat pantai ditemukan nyamuk dengan jumlah 5 spesies dan didominasi oleh spesies Ae.Albopictus dengan jumlah 10 individu. Ae. albopictus merupakan nyamuk yang dalam beberapa hal secara garis besar sangat mirip dengan $A e$. aegypti. Ae. albopictus merupakan nyamuk asli daerah timur, Asia dan sekitarnya yang menyebar ke daera barat seperti Mada gaskar dan pulau-pulau di Afrika Timur kecuali daratan benua Afrika sedangkan Ae. aegypti sebalinya berasal dari benua Afrika yang menyebar ke Timur mendominasi daera Asia Tenggara (Boesri 2011)

Tabel 1.Kelimpahan Individu Nyamuk di Setiap Habitat Desa Alindau

\begin{tabular}{|c|c|c|c|c|c|}
\hline \multirow{2}{*}{$\begin{array}{l}\text { Genus } \\
\text { Spesies }\end{array}$} & \multicolumn{4}{|c|}{ Habitat } & \multirow{2}{*}{ Jumlahindividu } \\
\hline & Pemukiman & Sawah & Pantai & Kebun & \\
\hline \multicolumn{6}{|l|}{ Aedes } \\
\hline Ae. albopictus & 9 & 12 & 10 & 10 & 41 \\
\hline Ae. vexans & 2 & 0 & 0 & 3 & 5 \\
\hline \multicolumn{6}{|l|}{ Anopheles } \\
\hline An. Indefinites & 0 & 1 & 0 & 0 & 1 \\
\hline An. peditaeniatus & 0 & 1 & 0 & 0 & 1 \\
\hline An. Vagus & 1 & 7 & 0 & 0 & 8 \\
\hline \multicolumn{6}{|l|}{ Armygeres } \\
\hline Ar. kuchingensis & 0 & 0 & 0 & 20 & 20 \\
\hline Ar. Subalbatus & 0 & 0 & 0 & 6 & 6 \\
\hline \multicolumn{6}{|l|}{ Culex } \\
\hline Cx. geliddus & 3 & 2 & 1 & 0 & 6 \\
\hline Cx. hutchinsoni & 2 & 0 & 1 & 0 & 3 \\
\hline $\begin{array}{l}\text { Cx. } \\
\text { qunquefasciatus }\end{array}$ & 34 & 10 & 8 & 0 & 52 \\
\hline Cx. vishnui & 54 & 26 & 7 & 2 & 89 \\
\hline Jumlah & 105 & 59 & 27 & 41 & 232 \\
\hline Keanekaragaman H' & $\mathrm{H}^{\prime} 1.49$ & $\mathrm{H}^{\prime} 1.32$ & $\mathrm{H}^{\prime} 1.31$ & $\mathrm{H}^{\prime} 1.21$ & \\
\hline
\end{tabular}


Menurut Boesri 2011, melaporkan perilaku nyamuk Ae. albopictus umumnya beristirahat di luar rumah dengan merenung dalam wadah alami atau buatan yang terlindung dari sinar matahari. Habitat atau lingkungan yang paling didambakan nyamuk ini adalah hutan dan taman. Di habitat kebun ditemukan nyamuk dengan jumlah 4 spesies dan didominasi oleh spesies Ar. kuchingensis dengan jumlah 20 individu. Dikarenakan pada habitat ini banyak terdapat selokan yang tidak mengalir dengan baik. Selokan tersebut menghasilkan genangan air yang dapat digunakan sebagai tempat untuk perkembangbiakan nyamuk. (Gambar 2)

Nilai keanekaragaman Shannon-Wiener tertinggi pada habitat sawah dengan nilai $H^{\prime}=1.49$. Sedangkan nilai keanekaragaman terendah dengan nilai $\mathrm{H}^{\prime}=1.21$ terdapat pada habitat pemukiman. Tingginya keanekaragaman pada habitat sawah, disebabkan karena habitat tersebut merupakan habitat yang sesuai sebagai tempat perindukan dan istirahat nyamuk. Richards et al. (2010) melaporkan bahwa semakin luas daerah persawahan maka semakin tinggi pula kelimpahan individu nyamuk. Selain itu pada habitat pantai dengan nilai $\mathrm{H}^{\prime}=1.32$ dan diikuti pada habitat kebun $\mathrm{H}^{\prime}=1.31$ terjadi karena dihabitat pantai dan habitat kebun merupakan habitat yang kondusif untuk tempat perkembangbiakan nyamuk. Hal tersebut dimungkinkan karena kondisi lingkungan dan habitat mendukung dalam perkembangbiakan populasinya.

Sebaran nyamuk berdasarkan waktu koleksi.Populasi yang tinggi ditemukan di empat habitat adalah spesies Culex vishnui (89 individu), Cx. qunquefasciatus (52 individu), Aedes albopictus (41 individu), Ar. kuchingensis (20 individu), An. vagus (8 individu), Ar. subalbatus (6 individu) $C u$. gellidus (6 individu), Ae. vexans (5 individu), $\mathrm{Cu}$. hutchinsoni (3 individu), Anopheles indefinitus (1 individu), An. peditaeniatus (1 individu). Hal tersebut dimungkinkan karena kondisi lingkungan dan habitat mendukung dalam perkembangbiakan populasinya. Aedes vexans dijumpai dari jam 18.00-21.00 WITA, Ae vexans merupakan nyamuk yang sifatnya aktif pada malam hari (nocturnal) sedangkan Ae. albopictus dijumpai dari jam 07.00-10.00 WITA. Nyamuk Ae. albopictus dimana kita ketahui nyamuk tersebut merupakan nyamuk yang sifatnya hanya aktif pada siang hari (diurnal). Anopheles vagus dijumpai dari jam 18.00-23.00 WITA. Anopheles indefinites dan An. peditaeniatu ditemukan jam 21.00 dan jam 23.00 WITA. Nyamuk An. vagus,An. indefinitus dan An. peditaeniatus merupakan nyamuk aktif pada malam hari. Sedangkan Ar. kuchingensis dijumpai dari jam 18.00-22.00 WITA dan 07.00-10.00 WITA dan Ar. subalbatus dijumpai dari jam 18.00-19.00 WITA dan 07.00-08.00-10.00 WITA. Spesies nyamuk Ar. kuchingensis dan Ar. subalbatus dapat di 
golongkan sebagai nyamuk yang disebut dengan nyamuk hutan yang di mana memiliki aktifitas menggigit yang aktif sepanjang hari (Crespuscular). Distribusi nyamuk ini tersebar di India, Indonesia, Malaysia, Myanmar, Nepal, Philipina, dan Thailad (Walker at al., 1998). Culex.visnui dijumpai sepanjang malam dari jam 18.0005.00 WITA, sedangkan $C x$. qunquefasciatus dijumpai dari jam 18.00-04.00. CX. hutchinsoni dijumpai pada jam 19.00, 22.00 dan 01.00 WITA dan Cx gellidus ditemukan pada jam 18.00, 21.00 dan 02.00-04.00 WITA. Perlu kita ketahui spesies nyamuk Cx. geliddus, CX. hutchinsoni, CX. qunquefasciatus dan $C x$. visnui merupakan nyamuk aktif pada malam hari.sedangkan pada siang hari nyamuk tersebut mancari tempat peristirahatan (Guimaraes dkk.,2000).

Berdasarkan hasil penelitian maka dapat disimpulkan bahwa jenis-jenis nyamuk yang ditemukan di Desa Alindau terdiri dari 11 spesies yaitu, Aedes vexsans, Ae. albopictus, Anopheles vagus, An. indefinitus, An. peditaeniatus, Ar. kuchingensis, Ar. subalbatus, Culex visnui, Cx. gellidus, Cx. qunquefasciatus, Cx. hutchinsoni.

Nilai Keanekaragaman tertinggi terdapat pada habitat sawah $\mathrm{H}^{\prime} 1.49$, diikuti pantai $\mathrm{H}^{\prime}$ 1.32, kebun $\mathrm{H}^{\prime}$ 1.31, dan pemukiman $\mathrm{H}^{\prime}$ 1.21dengan nilai keanekaragaman terendah.

\section{UCAPAN TERIMA KASIH}

Terima kasih kepada Saudara Abdul Samad, Andi, Fajrin, Rifkal dan Faldin yang telah membantu koleksi sampel di lapangan. Kepada kepala Desa Alindau yang telah memberi izin. Kepada Bapak Malonda Maksud S.KM. yang telah membantu dalam proses identifikasi sampel.

\section{DAFTAR PUSTAKA}

Boesri H., (2011). Biologi dan Peranan Aedes albopictus (Skuse) 1894 sebagai Penular Penyakit. Aspirator.3 : 117-125.

Boesri H., dkk. (2002). Penelitian untuk menentkan Indikator Entomolagi penyakit Demam Berdarah Dengue (DBD) di Daerah Endemis. Jurnal Kedokteran, 8(3): 72-79.

Depkes (Departemen Kesehatan RI). (2003). Laporan Tahunan Rencana strategi BPP Vektor Malaria Dan Filariasis Di Indonesia, hal.7-10, Jakarta.

Dharmawan R., (1993). Metode Identifikasi Spesies Kembar Nyamuk Anopheles. Sebelas Maret University Press. Surakarta.

Fahmi, M., Fahri, Nurwidayati, A., dan Suwastika, I N., (2014), Studi Keanekaragaman Spesies Nyamuk Anopheles sp. Di Kabupaten Donggala, Provinsi Sulawesi Tengah.Online Journal of Natural Science FMIPA, vol. 3(2): 95-108.

Gubler, D.J. (1998). Resurgent Vector-Borne Diseases asa Global Health Problem, Emerging Infectious Diseases.vol 4(3), 442-450. 
Guimaraes, A.E., C.Gentile, C.M. Lopes, R.P. de Mello. (2000). Ecology of Mosquitoes (Diptera: Culicidae) in Areas of Serra do Mar State Park, State of São Paulo, Brazil. III Daily Biting Rhythms and Lunar Cycle Influence. Mem Inst Oswaldo Cruz, Rio de Janeiro, Vol. 95(6): 753-760, Nov./Dec. 2000

Lestari, E.W., Sukowati, S., Soekidjo, S., dan Wigati, R.A. (2007). Vektor Malaria Didearah Bukit Menoreh, Purworejo, Jawa Tengah. Media penelitian dan pengembagan kesehatan 17 (1 maret).

O'connor, C.T., dan Soepanto, T. (1999). Identifikasi Nyamuk AnophelesBetina di Sulawesi. Ditjen P2MPL Depkes RI Tahun 2000.

Richards, Erin E., Masuoka, P., Brett, D., Smith, M., Kim, H.C., Anyamba, A. and Grieco, J. (2010). The Relationship Between Mosquito Abuance and Rice Field Density in The Republic of Korea. International Journal of Health Geographics. 9(32) : $1-10$.

Toma, T., Higa, Y and Miyagi, I. (2015). Distribution and breeding habitats of the Japanese encephalitis virus mosquito vector, Culex Vishnui, and other Culex Vishnui Subgroup species in the Ryukyu Archipelago, Jepan. Medical Entomology and Zoology,66(3), pp. 127-133.

Walker, ED., Torres. EP and Villanueva, RT. (1998). Componen of the vectorial capacity Aedes poilicius for Wuchereria bancrofti in Sorsogon porvince, Philippines. Annal of Tropical Medicine and Parasitology.92 (5): 603-14. 